\title{
New species of Procautires Kleine, 1925 from New Guinea (Coleoptera: Lycidae)
}

\author{
Новые виды Procautires Kleine, 1925 из Новой Гвинеи \\ (Coleoptera: Lycidae)
}

\author{
Sergey V. Kazantsev \\ C.В. Казанцев
}

Insect Centre, Donetskaya 13-326, Moscow 109651, Russia.

Инсект-центр, ул. Донецкая 13-326, Москва 109651, Россия. E-mail: kazantss@mail.ru

KEY WORDS: Coleoptera, Lycidae, new species, Papuan region.

КЛЮЧЕВЫЕ СЛОВА: Coleoptera, Lycidae, новые виды, Папусская область.

ABSTRACT. Fifteen new species of Procautires Kleine, 1925, $P$. aflabellatus, $P$. angustiformis, $P$. angustisuturalis, $P$. bicoloripectus, $P$. cladophoroides, $P$. cygnus, P. forficefer, P. maklaii, P. miklukhai, P. misoolensis, P. multipilosus, $P$. nabirensis, $P$. nigropumilio, $P$. sibelaensis and $P$. wauvagus spp.n., are described from New Guinea and adjacent islands. The autapomorphies of the genus are discussed.

РЕЗЮМЕ. Из Новой Гвинеи и с прилегающих островов описывается пятнадцать новых видов Procautires Kleine, 1925, $P$. aflabellatus, $P$. angustiformis, $P$. angustisuturalis, P. bicoloripectus, P. cladophoroides, P. cygnus, $P$. forficefer, P. maklaii, P. miklukhai, P. misoolensis, P. multipilosus, $P$. nabirensis, $P$. nigropumilio, $P$. sibelaensis и $P$. wauvagus spp.n. Обсуждаются аутапоморфии рода.

\section{Introduction}

The genus Procautires Kleine, 1925 is one of the endemics of the Australian and Papuan regions whose relationships are still not very clear. Twelve species of this genus have so far been known, with eleven recorded in New Guinea and on the adjacent islands [Kleine, 1925, 1926, 1933, 1935; Bocák, 2002]. Of these eleven species only in three male copulatory organs have been examined and illustrated [Kleine, 1926; Bocák, 2002], many of the remaining species described from females.

The present study represents a further contribution to the knowledge of this genus in New Guinea. It is based mostly on examination of lycid specimens from the Institut Royal de Sciences naturelles de Belgique, Bruxelles, collected by Dr. Olivier Missa in 1993-1996 in Madang province, Papua New Guinea. Examination of this, as well as some additional material, including that collected on the adjacent islands, allows describing another fifteen species of this genus, which brings the number of Procautires species reported from the region to twenty six.

\section{Material and Methods}

Collecting methods yielding all net-winged beetles from Madang were light traps and canopy fogging. The collecting site was located in the centre of Baiteta forest $\left(05^{\circ} 01^{\prime} \mathrm{S}, 145^{\circ} 45^{\prime} \mathrm{E}\right), 4 \mathrm{~km}$ inland from the Papua New Guinea northern coast in the Madang province and 50100 meters above sea level. Baiteta forest is a remnant patch of lowland mixed tropical rainforest with a relatively high canopy of 35-40 m [Riedel, 2008].

The studied specimens were glued on cardboard plates. For a detailed examination they were relaxed in water; then the detached ultimate abdominal segments were treated for several hours in $10 \% \mathrm{KOH}$ at room temperature, then, with the extracted genitalia, placed in microvials with glycerin; or glued back on cardboard plates, along with the extracted genitalia, without the $\mathrm{KOH}$ treatment.

MSP-1 zoom stereoscopic dissecting microscope with $\mathrm{x} 8-\mathrm{x} 80$ magnification range was used. Photographs were taken with Canon EOS 6D camera and Canon MP-E $65 \mathrm{~mm}$ lens.

The following acronyms are used in the paper:

ICM - Insect Center, Moscow;

IRSN — Institut Royal de Sciences naturelles de Belgique, Bruxelles;

NME — Naturkundemuseum, Erfurt.

\section{Taxonomy}

Procautires Kleine, 1925

Procautires Kleine, 1925: 32

type species: P. toxopei Kleine, 1925: 32 (by monotypy)

Procautires angustiformis Kazantsev, sp.n. Figs 1-3.

MATERIAL: Holotype, $\sigma^{\top}$, Papua New Guinea, Madang prov., Baiteta, light, 16.IV.1996, O. Missa leg. (IRCN); paratypes, $40^{7} \sigma^{7}$, same label, dates: 2.VII.1995; 15.V.1996; 24.VI.1996; 3.VII.1996 (ICM and IRCN). 
DESCRIPTION. Male. Dark brown to black; frons, antennomere 2, lateral pronotal margins, pro- and mesocoxae, trochanters, femoris, except distally, and tibiae proximally testaceous.

Vertex shining, finely punctate, with shallow transverse impression behind antennal prominence. Eyes relatively small, interocular distance ca. 1.6 times greater than eye diameter. Labrum moderately large, transverse, emarginate medially. Palps slender, ultimate palpomeres elongate, pointed and glabrous distally. Antennal sockets separated by narrow lamina. Antennae flattened, narrow, feebly dentate, attaining to elytral two thirds; antennomere $3 \mathrm{ca}$. 9 times longer than antennomere 2 and subequal in length to antennomere 4; antennomeres 3-11 with short sub-erect pubescence (Fig. 1).

Pronotum transverse, ca. 1.3 times as wide as long, with almost parallel sides, bisinuate basally and rounded anteriorly, with small acute posterior and conspicuous blunt anterior angles; median cell moderately broad, reaching anterior margin; lateral carinae curved; anterior cells slightly diverging anteriorly, formed by straight antero-lateral carinae. Mesothoracic spiracle with minute erect hood. Scutellum subquadrate, slightly narrowing distally, emarginate at apex (Fig. 1).

Elytra narrow, long, ca. 4.5 times longer than wide at humeri, parallel-sided, with strong, equally developed primary costae; interstices 1 and 5 with double row of regular roundish cells at proximal and distal sixths; interstices 2-4 with double rows of cells only at proximal sixth; bottom of cells glabrous; pubescence mostly along costae, short and decumbent (Fig. 1).
Tibiae and femoris straight, broad; tarsi moderately widened, tarsomeres 1-4 with plantar pad.

Aedeagus with elongate, narrow and considerably widened apically median lobe; inner sac with disk-like sclerotised structure; membrane of phallobase with inner sclerotised structure (Figs 2-3).

Female. Unknown.

Length: 5.7-6.4 mm. Width (humerally): $1.2-1.4 \mathrm{~mm}$.

ETYMOLOGY. The name of the new species is derived from the Latin for "of narrow constitution", alluding to its shape.

DIAGNOSIS. Procautires angustiformis sp.n. can be separated from $P$. maculosus Kleine, 1926, also with lighter pronotal sides, by the less conspicuous anterior pronotal angles and parallel-sided elytra (Fig. 1).

VARIATION. In two of the paratypes of $P$. angustiformis sp.n. elytral interstices 2 and 4 have a double row of cells distally as well.

\section{Procautires angustisuturalis Kazantsev, sp.n.}

Figs 4-6.

MATERIAL: Holotype, $\sigma^{7}$, Papua New Guinea, Madang prov., Baiteta, light, 5.V.1996, O. Missa leg. (IRCN); paratypes, $5 \sigma^{7} \sigma^{7}$, same label, dates: 11.IV.1996; 24.IV.1996; 25.IV.1996; 15.V.1996; 15.VII.1996; 2 우, same label, dates: 7.VI.1993; 9.IV.1996 (ICM and IRCN)

DESCRIPTION. Male. Dark brown; antennomere 2 and very bases of other antennomeres, pronotum, except bottom
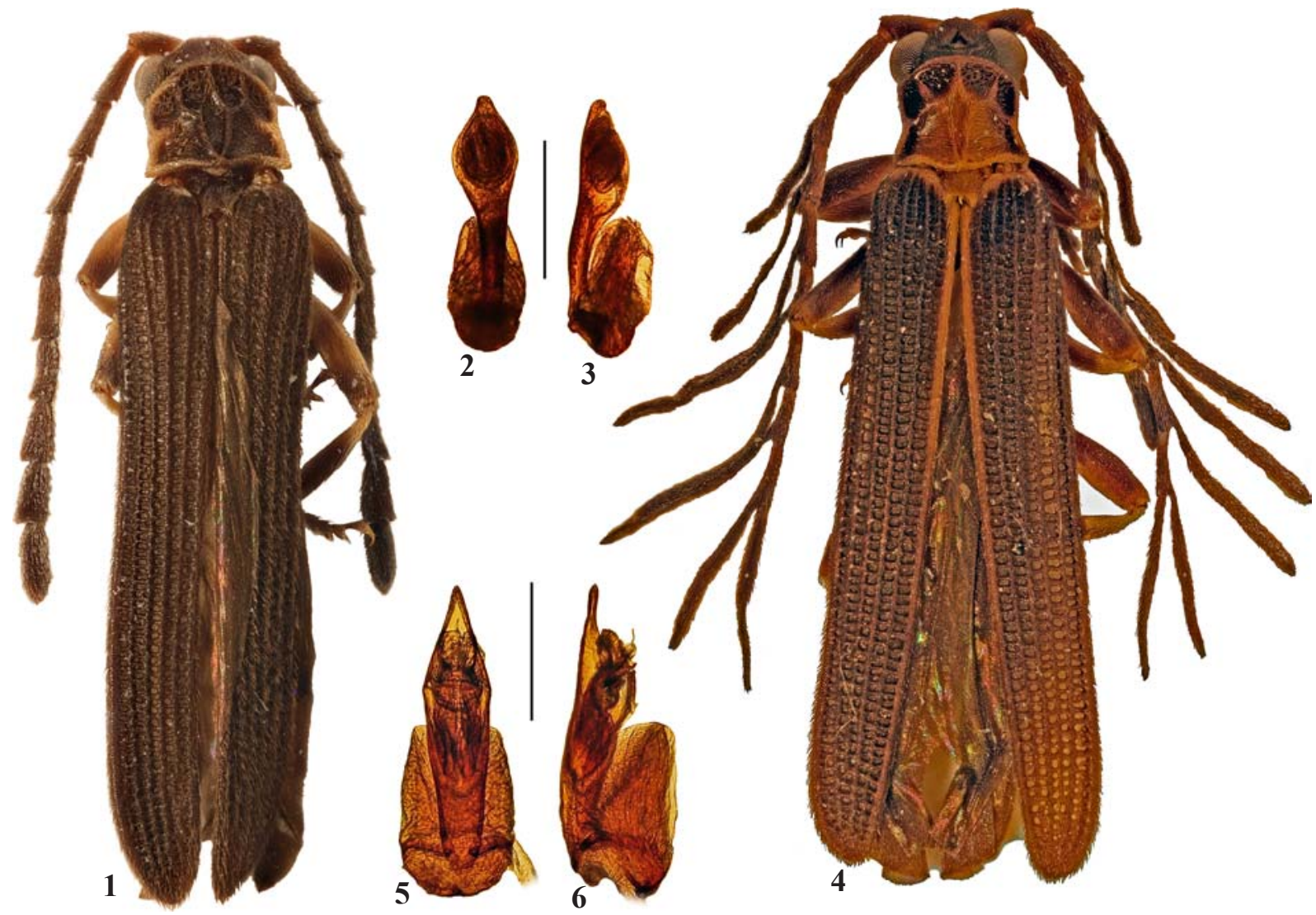

Figs 1-6. General view and aedeagi of Procautires, holotypes, males: 1-3 - P. angustiformis sp.n.; 4-6 - P. angustisuturalis sp.n.; 1, 4 - general view; 2-3, 5-6 - aedeagi; 1-2, 4-5 - dorsally; 3, 6 - laterally. Scale bar: $0.5 \mathrm{~mm}$.

Рис. 1-6. Общий вид и эдеагусы Procautires, голотипы, самцы: 1-3 - P. angustiformis sp.n.; 4-6 - P. angustisuturalis sp.n.; 1, 4 - общий вид; 2-3, 5-6 - эдеагусы; 1-2, 4-5- сверху; 3, 6- сбоку. Масштабная линейка: 0.5 мм. 
of anterior areoles, scutellum, elytral anterior margin, suture at proximal half and lateral margins under shoulders, pro- and mesocoxae, trochanters and bases of femoris and tibiae orange testaceous.

Head with short rostrum. Vertex with small deep triangular impression just behind antennal prominence. Eyes moderately large, interocular distance only slightly greater than eye diameter. Labrum relatively large, transverse, rounded anteriorly. Palps slender; ultimate palpomeres small, elongate, narrowing distally and glabrous at apex. Antennal sockets separated by minute lamina. Antennae almost attaining to elytral apices, from antennomere 4 flabellate; antennomere 3 ca. 8 times longer than antennomere 2 and 1.3 times longer than antennomere 4; flabella of antennomere 4 ca. 2.4 times longer than stem, flabella of antennomere 5 ca. 3.2 times

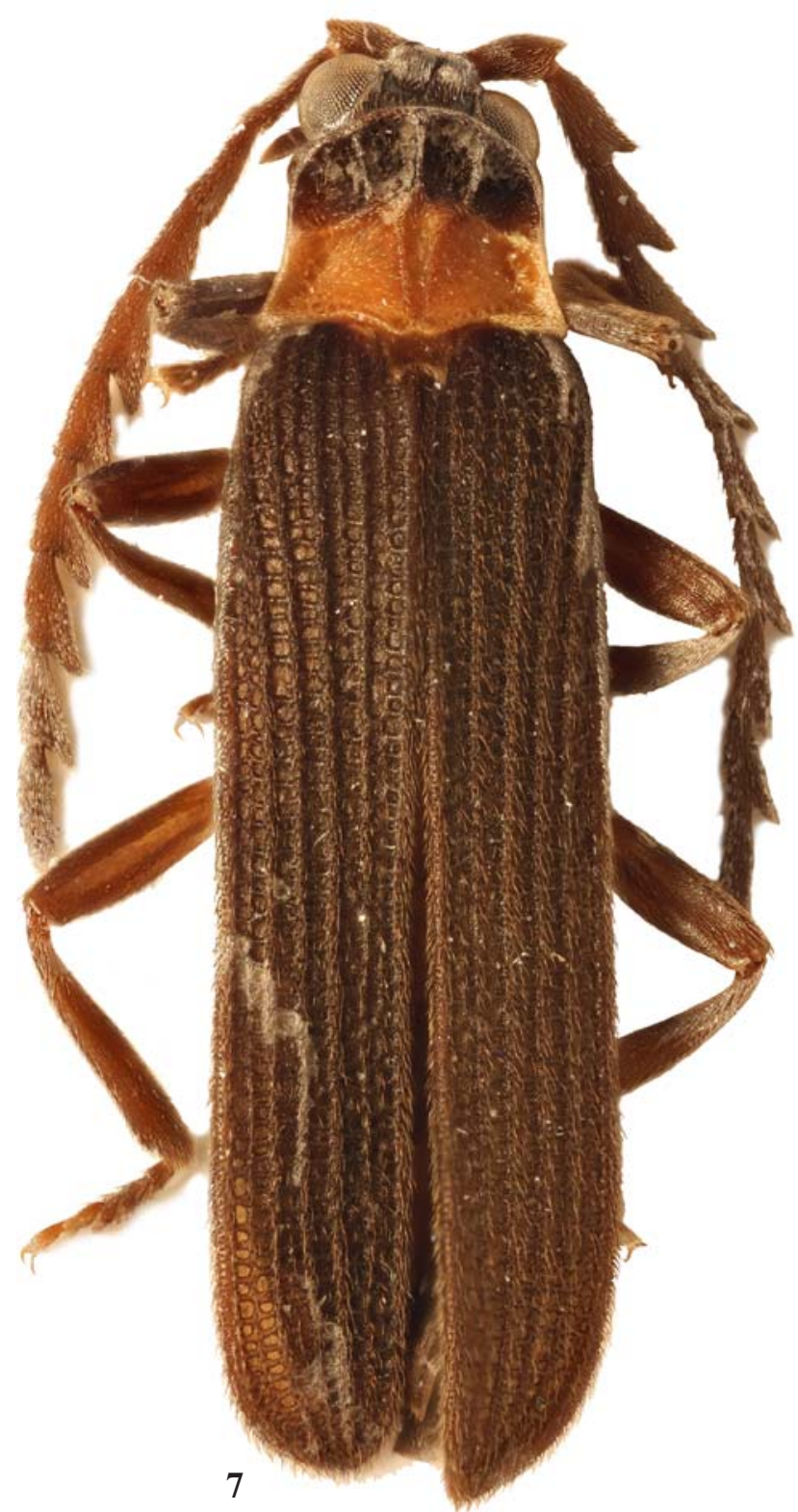

longer than stem; antennomeres 3-11 with short sub-erect pubescence (Fig. 4).

Pronotum transverse, ca. 1.2 times as wide as long, noticeably incised at sides below middle, bisinuate basally and rounded anteriorly, with acute posterior and evident blunt anterior angles; median cell moderately broad, extending almost to anterior margin; lateral carinae curved; anterior cells diverging anteriorly, formed by short straight anterolateral carinae. Mesothoracic spiracle hooded; hood narrow, sub-erect. Scutellum transverse, slightly narrowing distally, semi-circularly emarginate at apex (Fig. 4).

Elytra long, ca. 3.8 times longer than wide at humeri, parallel-sided, with strong, equally developed primary costae; interstice 5 with double row of regular mostly transverse cells at proximal and distal fifths; interstices $1-4$ with double rows

Figs 7-11. General view and aedeagus of Procautires bicoloripectus sp.n., holotype, male: 7 - general view; 8-9 - aedeagus; 10-11 external female genitalia; 7-8, 10 - dorsally; 9,11 - laterally. Scale bars: $0.5 \mathrm{~mm}$.

Рис. 7-11. Общий вид и эдеагус Procautires bicoloripectus sp.n., голотип, самец: 7 - общий вид; 8-9 - эдеагус; 10-11 наружные женские гениталии; 7-8, 10 - сверху; 9, 11 - сбоку. Масштабные линейки: 0.5 мм. 
of cells only at proximal fifth; bottom of cells glabrous; pubescence mostly along costae, short and decumbent (Fig. 4).

Tibiae and femoris straight, narrow; tarsi widened, tarsomeres 1-4 with plantar pad.

Aedeagus with relatively broad, widened towards proximal two thirds and pointed distally median lobe; inner sac with widened distally sclerotised structure; membrane of phallobase ca. half as long as median lobe, with inner sclerotised structure (Figs 5-6).

Female. Similar to male, but eyes somewhat smaller, antennae dentate proximally and feebly flabellate distally.

Length: $6.9-9.6 \mathrm{~mm}$. Width (humerally): $1.5-2.1 \mathrm{~mm}$

ETYMOLOGY. The name of the new species is derived from the Latin for "with narrow suture", alluding to its coloration.

DIAGNOSIS. Procautires angustisuturalis sp.n. is readily separated from the somewhat similar $P$. cladophoroides sp.n. by the coloration, with major part of pronotum and only elytral suture orange testaceous, non-flabellate antennomere 3 and much longer flabellae of consequent antennomeres and structure of the aedeagus (Figs 4-6).

\section{Procautires bicoloripectus Kazantsev, sp.n.} Figs 7-11.

MATERIAL: Holotype, $O^{7}$, Papua New Guinea, Madang prov., Baiteta, fogging, 26.V.1995, O. Missa leg. (IRCN); paratypes, 3 $\sigma^{7} \sigma^{7}$, same label; $26 \sigma^{7} \sigma^{7}$, Papua New Guinea, Madang prov. Baiteta, light, O. Missa leg., dates: 22.IV.1996; 25.IV.1996 (3 specimens); 15.V.1996 (2 specimens); 16.V.1996; 20.V.1996; 28.V.1996; 30.V.1996; 10.VI.1996; 18.VI.1996; 20.VI.1996 (3 specimens); 24.VI.1996 (4 specimens); 25.VI.1996 (2 specimens); 27.VI.1996; 11.VII.1996 (2 specimens); 27.VII.1996; ㅇ, Papua New Guinea, Madang prov., Baiteta, light, 16.V.1996, O. Missa leg. (ICM and IRCN).

DESCRIPTION. Male. Dark brown to black; antennomere 2, posterior half of pronotum, trochanters and bases of femoris orange testaceous.

Vertex with conspicuous transverse impression behind antennal prominence. Eyes relatively large, interocular distance subequal in length to eye diameter. Labrum relatively large, rounded, slightly emarginate medially. Palps slender; ultimate palpomeres elongate, conspicuously narrowed and glabrous at apex. Antennal sockets separated by narrow lamina. Antennae attaining to elytral two thirds, from antennomere 3 dentate; antennomere 3 ca. 8 times longer than antennomere 2 and 1.1 times longer than antennomere 4; antennomeres 3-11 with short decumbent pubescence with longer erect bristles at distal margin (Fig. 7).

Pronotum transverse, ca. 1.4 times wider than long, slightly narrowing and rounded anteriorly, bisinuate basally, with moderately protruding acute posterior and inconspicuous blunt anterior angles; median cell narrow, extending to 0.65 pronotal length; lateral carinae almost straight; anterior cells slightly diverging anteriorly, formed by straight antero-lateral carinae. Mesothoracic spiracle hooded; hood long, flattened, bent posteriad and pressed to mesepisternum. Scutellum transverse, narrowing distally, conspicuously emarginate at apex (Fig. 7).

Elytra long, ca. 3.3 times longer than wide at humeri, parallel-sided, with strong, equally developed primary costae; interstices 1 and 5 with double rows of regular roundish cells; interstices 2, 3 and 4 with double rows of cells only at proximal sixth (fifth in case of interstice 2) and distally; bottom of cells glabrous; pubescence mostly along costae, short and decumbent (Fig. 7).

Tibiae and femoris straight, broad; tarsi widened, tarsomeres 1-4 with plantar pad.
Aedeagus with elongate, relatively narrow, almost parallel-sided median lobe, triangularly narrowed at apex; inner sac with racket-like sclerotised structure (Figs 8-9).

Female. Similar to male, but antennae shorter. Spiculum ventrale short, about half as long as the ventrite, narrow. Valvifers very narrow and ca. 2.1 times longer than coxites; coxites elongate, relatively narrow, approximate, but separated at base; styli elongate; spermatheca spiral, with smalldiameter coils (Figs 10-11).

Length: 5.2-7.9 mm. Width (humerally): $1.3-2.1 \mathrm{~mm}$.

ETYMOLOGY. The name of the new species is derived from the Latin for "two-coloured chest", alluding to its coloration.

DIAGNOSIS. Procautires bicoloripectus sp.n. can be separated from the apparently related $P$. forficefer sp.n. by the orange testaceous posterior pronotal half and conspicuously more elongate and narrow median lobe of the aedeagus and racket-like, i.e with rounded apex, inner sac structure (Figs 7-9)

\section{Procautires cladophoroides Kazantsev, sp.n.} Figs 12-14.

MATERIAL: Holotype, $0^{\top}$, Papua New Guinea, Madang prov., Baiteta, light, 16.IV.1996, O. Missa leg. (IRCN); paratypes, $60^{7} \sigma^{7}$, same label, dates: 8.VII.1996; 17.VI.1996; 27.IV.1995; 18.VII.1996; 3.VII.1996; 4 우, same label, dates: 23.IV.1996; 25.IV.1996; 20.V.1996; 10.VII.1996; 2 O $^{\top} \sigma^{7}$ and ${ }^{\circ}$, Papua New Guinea, Madang prov., Baiteta, fogging, 27.IV.1995, O. Missa leg. (ICM and IRCN); $30^{7} 0^{7}$. Indonesia, Irian Jaya, Nabire area, road Nabire-Ilaga, km 62, 0330'936'S, 13541'945'”E, 250 m, X.1997, M. Balke leg. (ICM and NME).

DESCRIPTION. Male. Dark brown to black; antennomere 2 and very bases of other antennomeres, pronotal margins and two basal pronotal spots, scutellum, elytral anterior margin, interstices 1-2 at anterior half and lateral margins under shoulders, pro- and mesocoxae, trochanters and bases of femoris and tibiae orange testaceous.

Head with short rostrum. Vertex with small deep triangular impression behind antennal prominence. Eyes small, interocular distance ca. 1.6 times greater than eye diameter. Labrum relatively large, transverse, rounded anteriorly. Palps slender; ultimate palpomeres elongate, slightly widened distally, obliquely truncate and glabrous at apex. Antennal sockets separated by minute lamina. Antennae almost attaining to elytral apices, from antennomere 3 flabellate; antennomere $3 \mathrm{ca} .8$ times longer than antennomere 2 and 1.3 times longer than antennomere 4; flabella of antennomere $3 \mathrm{ca} .1 .5$ times shorter than stem, flabella of antennomere 4 ca. 1.3 times longer than stem, flabella of antennomere 5 ca. 1.7 times longer than stem; antennomeres 3-11 with short suberect pubescence (Fig. 12).

Pronotum transverse, ca. 1.3 times as wide as long, parallel-sided, slightly bisinuate basally and feebly convex anteriorly, with small acute posterior and noticeable blunt anterior angles; median cell relatively broad, extending to anterior margin; lateral carinae straight; anterior cells almost not diverging anteriorly, formed by straight antero-lateral carinae. Mesothoracic spiracle hooded; hood flattened and bent posteriad. Scutellum transverse, parallel-sided, emarginate at apex (Fig. 12).

Elytra long, ca. 3.2 times longer than wide at humeri, parallel-sided, with strong, equally developed primary costae; interstices 1 and 5 with double rows of regular transverse cells at proximal and distal fourths; interstices 2-4 with double rows of cells only at proximal fourth, with vague traces of secondary costae elsewhere; bottom of cells glabrous; pubescence mostly along costae, short and decumbent (Fig. 12). 
Tibiae and femoris straight, narrow; tarsi widened, tarsomeres 1-4 with plantar pad.

Aedeagus with straight, narrow, slightly widened and abruptly constricted near apex median lobe; inner sac with two pairs of narrow, almost straight spines and short semicircular outer process; phallobasal membrane with inner sclerotised structure (Figs 13-14).

Female. Similar to male, but antennae dentate proximally and feebly flabellate distally.

Length: 8.4-10.4 mm. Width (humerally): $1.7-2.4 \mathrm{~mm}$.

ETYMOLOGY. The name of the new species is derived from the genus name Cladophorus Guerin-Meneville, 1833 , alluding to the similarity this species has with the aforesaid taxon.

DIAGNOSIS. Procautires cladophoroides sp.n. seems to be related to $P$. suturalis Kleine, 1926, differing by the more elongate antennal flabellae, which are considerably longer than relevant stems, and shorter and more dilated distally apex of the median lobe of the aedeagus (Figs 12-14).

REMARKS. Paratypes from Irian Jaya have elytral anterior fourth entirely orange testaceous, with orange testaceous triangle spreading to elytral middle along the suture.

\section{Procautires forficefer Kazantsev, sp.n.} Figs 15-17.

MATERIAL: Holotype, $\sigma^{7}$, Papua New Guinea, $10 \mathrm{~km} \mathrm{~N}$ Madang, 2 km NNW Riwo, 9-11.II.1989, M. \& R. Holyñski leg. (ICM); paratype, $O^{7}$, same label (ICM).

DESCRIPTION. Male. Dark brown; antennomere 2, pro- and mesocoxae, trochanters, bases of femoris light brown to testaceous.
Vertex glabrous, with prominent transverse impression behind antennal prominence. Eyes relatively small, interocular distance ca. 1.5 times greater than eye diameter. Labrum relatively large, rounded and slightly emarginate anteriorly. Palps slender; ultimate palpomeres elongate, conspicuously narrowed and glabrous at apex. Antennal sockets separated by minute lamina. Antennae attaining to elytral two thirds, from antennomere 3 dentate; antennomere 3 ca. 7 times longer than antennomere 2 and ca. 1.1 times longer than antennomere 4; antennomeres 3-11 with short decumbent pubescence (Fig. 15).

Pronotum transverse, ca. 1.4 times as wide as long, trapezoidal, bisinuate basally, with prominent acute posterior and inconspicuous blunt anterior angles; median cell narrow, extending to 0.6 pronotal length; lateral carinae almost straight; anterior cells diverging anteriorly, formed by almost straight antero-lateral carinae. Mesothoracic spiracle hooded; hood long, flattened, bent posteriad and pressed to mesepisternum. Scutellum transverse, noticeably narrowing distally, triangularly emarginate at apex (Fig. 15).

Elytra long, ca. 3.1 times longer than wide at humeri, parallel-sided, with strong, equally developed primary costae; interstices 1, 2 and 5 with double rows of regular roundish cells; interstices 3 and 4 with double rows of cells only at proximal and distal fifths; bottom of cells glabrous; pubescence mostly along costae, short and decumbent (Fig. 15).

Tibiae and femoris straight, broad; tarsi widened, tarsomeres 1-4 with plantar pad.

Aedeagus with relatively short and broad median lobe with scissors-like inner sac structure (Figs 16-17).

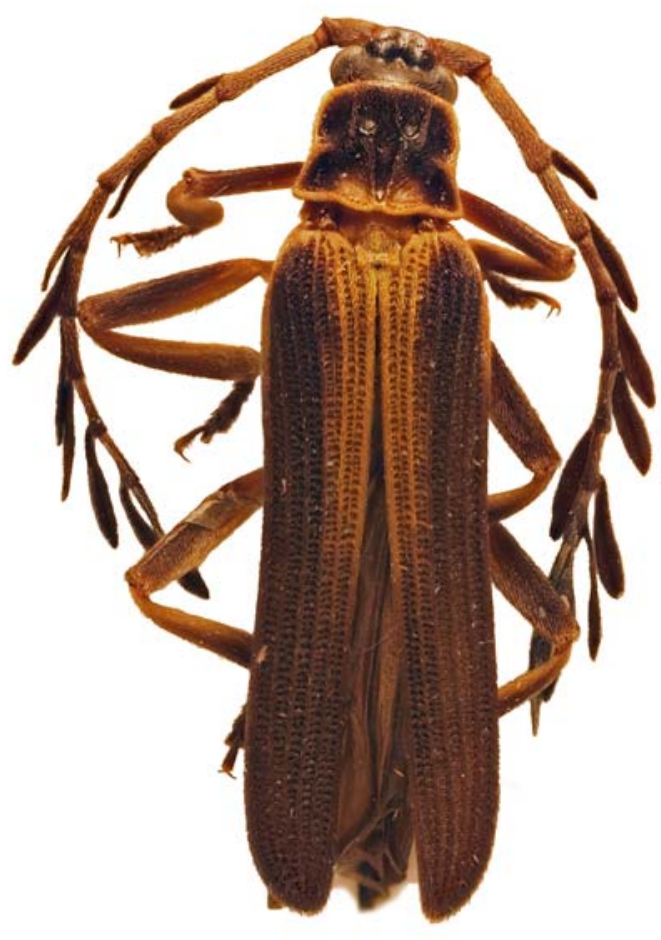

12

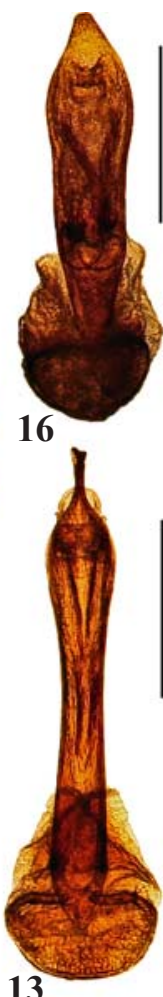

13
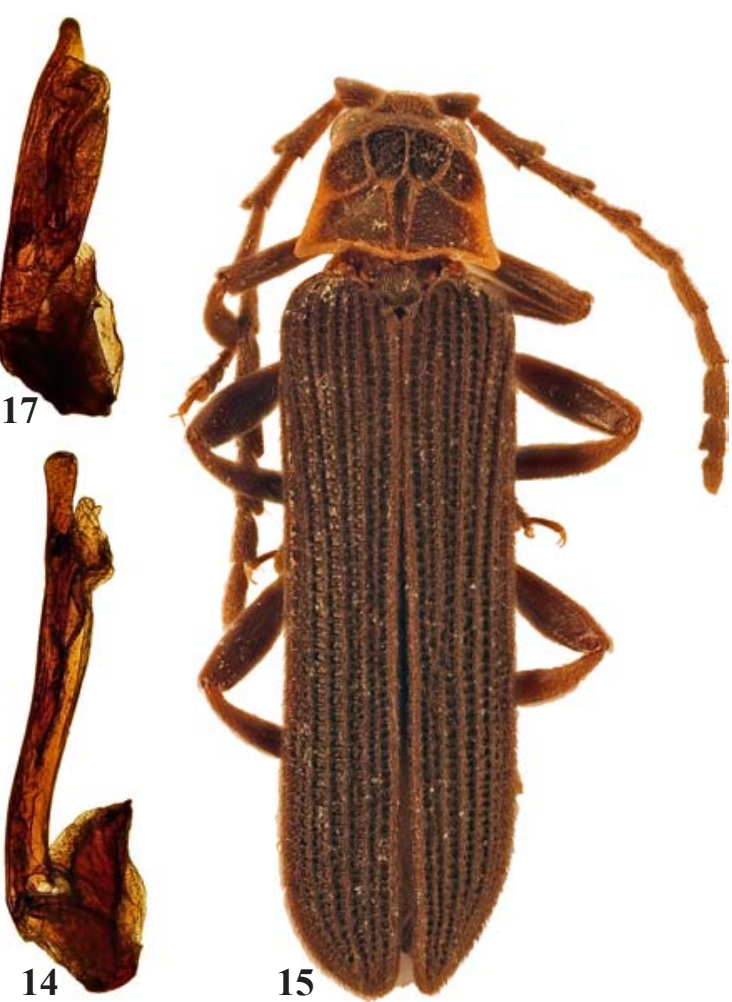

Figs 12-17. General view and aedeagi of Procautires, holotypes, males: 12-14 - P. cladophoroides sp.n.; $15-17-P$. forficefer sp.n.; 12, 15 - general view; 13-14, 16-17 - aedeagi; 12-13, 15-16 - dorsally; 14, 17 - laterally. Scale bar: 0.5 mm.

Рис. 12-17. Общий вид и эдеагусы Procautires, голотипы, самцы: 12-14 - P. cladophoroides sp.n.; 15-17 - P. forficefer sp.n.; 12,15 - общий вид; 13-14, 16-17 - эдеагусы; 12-13, 15-16 - сверху; 14, 17 - сбоку. Масштабная линейка: 0.5 мм. 
Female. Unknown.

Length: 7.0-7.4 mm. Width (humerally): $1.8-1.9 \mathrm{~mm}$.

ETYMOLOGY. The name of the new species is derived from the Latin for "carrying scissors", alluding to shape of its inner sac structure.

DIAGNOSIS. Procautires forficefer sp.n. is apparently related to $P$. bicoloripectus sp.n., but may be distinguished by the infuscated pronotum with only lighter margins at posterior angles, smaller eyes and noticeably shorter and broader median lobe of the aedeagus with scissors-like inner sac structure (Figs 15-17).

\section{Procautires misoolensis Kazantsev, sp.n Figs 18-19.}

MATERIAL: Holotype, O , E Indonesia, Raja Ampat, S Misool, distr. Misool Barat, env. Lilinta (Lelintah), $02^{\circ} 02^{\prime} 54^{\prime \prime} S$, $130^{\circ} 16^{\prime} 19^{\prime \prime} \mathrm{E}$, secondary moist lowland forest on limestone, beaten from branches, 01.IV.2009, D. Telnov \& K. Greke leg. (NME)

DESCRIPTION. Male. Dark brown to black; antennomere 2, pronotal margins and lateral carinae, elytra at proximal fifth and trochanters testaceous.

Head without rostrum. Vertex with deep round impression behind antennal prominence. Eyes small, interocular distance ca. 1.5 times greater than eye diameter, bulging. Labrum small, strongly transverse, slightly emarginate medially. Palps slender; ultimate palpomeres small, elongate, parallel-sided, flattened and glabrous at apex. Antennal sockets separated by minute lamina. Antennae almost attaining to elytral apices, from antennomere 4 flabellate; antennomere 3 ca. 9 times longer than antennomere 2 and 1.1 times longer than antennomere 4; flabella of antennomere 4 ca. 2 times shorter than stem, flabella of antennomere 5 subequal in length to stem; antennomeres 3-11 with short decumbent pubescence (Fig. 18).

Pronotum transverse, ca. 1.3 times wider than long, trapezoidal, very slightly produced anteriorly and slightly bisinuate at base, with small acute posterior and prominent almost right anterior angles; median cell broad, extending to anterior margin; lateral carinae straight; anterior cells diverging anteriorly, formed by straight antero-lateral carinae. Scutellum transverse, narrowing distally, slightly emarginate at apex (Fig. 18).

Elytra long, ca. 3.6 times longer than wide at humeri, parallel-sided, with strong, equally developed primary costae; interstice 5 with double row of regular subquadrate cells at proximal and distal fifths; interstices 1-4 with double rows of cells only at proximal fifth; bottom of cells glabrous; pubescence mostly along costae, short and decumbent (Fig. 18).

Tibiae and femoris straight, narrow; tarsi widened, tarsomeres 1-4 with plantar pad.

Aedeagus with straight, narrow proximally, gradually widened to apex median lobe, apex triangularly pointed (Fig. 19).

Female. Unknown.

Length: $6.6 \mathrm{~mm}$. Width (humerally): $1.4 \mathrm{~mm}$.

ETYMOLOGY. The name of the new species is derived from the name of the island where the type specimen was collected.

DIAGNOSIS. Procautires misoolensis sp.n. somewhat resembles $P$. angustisuturalis sp.n., but may be easily distinguished by the elytral coloration with testaceous shoulders
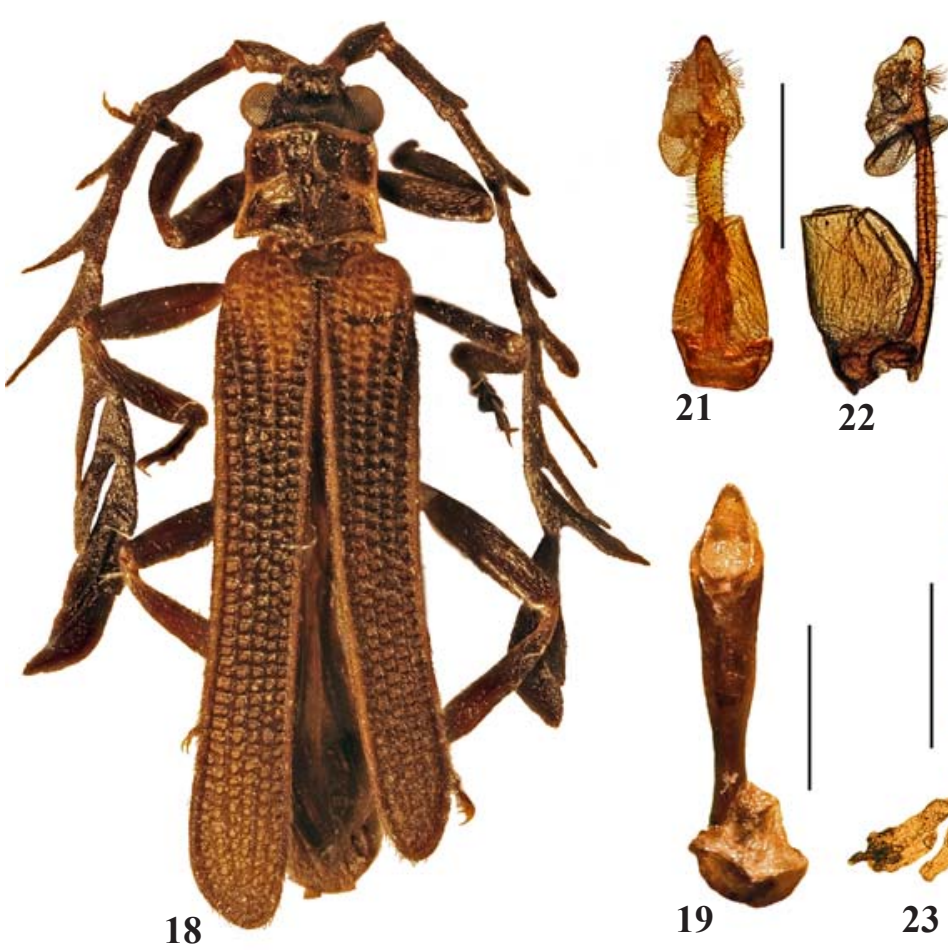

22
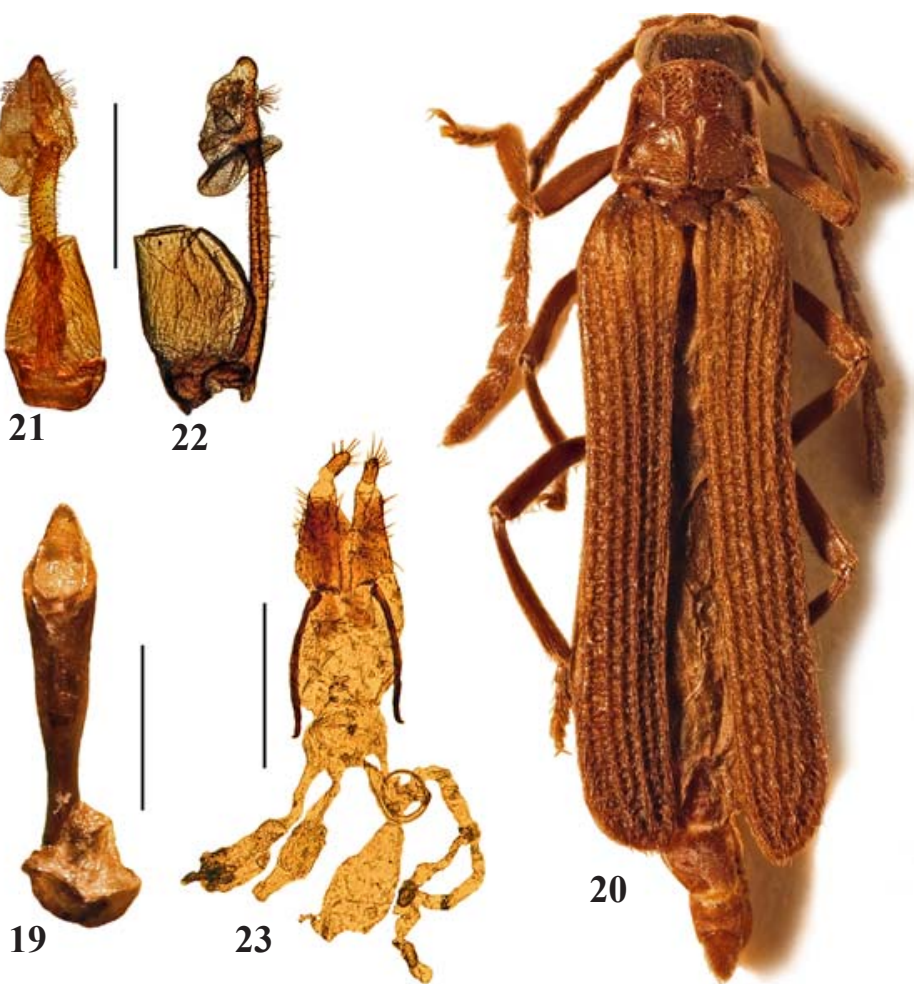

Figs 18-23. General view and detals of Procautires: 18-19-P. misoolensis sp.n.; 20-23 - P. multipilosus sp.n.; 18, 20 - general view; 19, 21-22 - aedeagi; 23 - external female genitalia; 18-22 - holotypes, males; 23 - paratype, female; 18-21, 23 - dorsally; 22 - laterally. Scale bars: $0.5 \mathrm{~mm}$.

Рис. 18-23. Общий вид и детали строения Procautires: 18-19-P. misoolensis sp.n.; 20-23 - P. multipilosus sp.n.; 18, 20- общий вид; 19, 21-22 - эдеагусы; 23 - наружные женские гениталии; 18-22 - голотипы, самцы; 23 - паратип, самка; 18-21, 23 - сверху; 22 - сбоку. Масштабные линейки: 0.5 мм. 
and conspicuously shorter antennal flabellae, as well as by the more narrow proximal part of the median lobe of the aedeagus (Figs 18-19).

\section{Procautires multipilosus Kazantsev, sp.n. Figs 20-23.}

MATERIAL: Holotype, $\bigcirc^{7}$, Papua New Guinea, Madang prov., Baiteta, fogging, 1.VI.1994, O. Missa leg. (IRCN); paratypes, $\sigma^{7}$, same label; 5 90 , Papua New Guinea, Madang prov., Baiteta, fogging, 26.V.1995, O. Missa leg. (2 specimens); Papua New Guinea, Madang prov., Baiteta, light, 30.IV.1996, O. Missa leg.; Papua New Guinea, Madang prov., Baiteta, light, 14.V.1996, O. Missa leg.; Papua New Guinea, Madang prov., Baiteta, light, 3.VI.1996, O. Missa leg. (ICM and IRCN).

DESCRIPTION. Male. Dark brown; head black.

Head with short rostrum. Vertex with transverse impression behind antennal prominence. Eyes small, interocular distance ca. 1.5 times greater than eye diameter, not bulging. Labrum slightly wider than long, trapezoidal, inconspicuously emarginate medially. Palps slender; ultimate palpomeres small, elongate, pointed and glabrous at apex. Antennal sockets separated by narrow lamina. Antennae flattened, dentate, relatively short, attaining to elytral three fifths; antennomere $3 \mathrm{ca} .8$ times longer than antennomere 2 and subequal in length to antennomere 4; antennomeres 3-11 with short sub-erect pubescence (Fig. 20).

Pronotum transverse, ca. 1.25 times as wide as long, trapezoidal, slightly bisinuate basally and convex anteriorly, with small acute posterior and noticeable blunt anterior angles; median cell moderately broad, extending to 0.7 pronotal length; anterior ribs of median diamond suppressed with anterior median carina strengthened; lateral carinae straight; anterior cells not diverging anteriorly, formed by straight antero-lateral carinae. Mesothoracic spiracle not hooded. Scutellum transverse, slightly narrowing distally, triangularly emarginate at apex (Fig. 20).

Elytra long, ca. 3.3 times longer than wide at humeri, widest near humeri, in distal two thirds parallel-sided, with four primary costae; primary costae 2 and 4 noticeably stronger than others; interstice 5 with double row of small irregular cells at proximal and distal fifths; interstices 2-4 with double rows of cells only at proximal fifth; pubescence mostly along costae, short and decumbent (Fig. 20).

Tibiae and femoris straight, narrow; femoris with relatively long erect vestiture on inner side; tarsi widened, tarsomeres 1-4 with plantar pad.

Aedeagus with narrow straight median lobe in dense erect vestiture; inner sac with a pair of lateral brushes of bristles; phallobase with elongate well-sclerotised parameres-like process semi-enveloping median lobe (Figs 21-22).

Female. Similar to male, but antennae shorter and femoris without long vestiture. Valvifers very narrow and noticeably longer than coxites; coxites elongate, broad, separated proximally; styli elongate, slightly longer than wide; spermatheca spiral, with two tight large-diameter coils; paraproct elongate, oval, bifurcate and truncate proximally (Fig. 23).

Length: $5.6-7.8 \mathrm{~mm}$. Width (humerally): $1.2-1.7 \mathrm{~mm}$.

ETYMOLOGY. The name of the new species is derived from the Latin for "with much pubescence", alluding to the pubescence of its aedeagus and the meso- and metafemoral vestiture.

DIAGNOSIS. Procautires multipilosus sp.n. is easily distinguishable from other Procautires species by the semiopen anteriorly median pronotal cell, unhooded mesothoracic spiracle, structure of the aedeagus, with hairy narrow median lobe and prominent membranous inner sac, and exter- nal female genitalia, with long valvifers and spiral spermatheca (Figs 20-23).

REMARKS. Procautires multipilosus sp.n. is the only lycid species from Baiteta forest with greater part of specimens of the type series collected by fogging.

\section{Procautires nabirensis Kazantsev, sp.n.}

Figs 24-26.

MATERIAL: Holotype, $\sigma^{7}$, Indonesia, Irian Jaya, Nabire area, 750 m, 28.V.1995, V. Tuzov leg. (ICM).

DESCRIPTION. Male. Dark brown to black; antennomere 2 light brown.

Vertex coarsely punctate, with longitudinal median groove behind antennal prominence. Eyes small, interocular distance ca. 1.7 times greater than eye diameter, bulging. Labrum small, transverse, semicircular. Palps slender; ultimate palpomeres small, elongate, parallel-sided, dentate and glabrous at apex. Antennal sockets separated by minute lamina. Antennae attaining to elytral two thirds, from antennomere 3 flabellate; antennomere 3 ca. 8 times longer than antennomere 2 and subequal in length to antennomere 4; flabella of antennomere ca. 0.7 length of stem, flabella of antennomere 4 ca. 1.6 times longer than stem; antennomeres 3-11 with short sub-erect pubescence and small roundish scales (Fig. 24).

Pronotum transverse, ca. 1.5 times wider than long, slightly trapezoidal, convex anteriorly and bisinuate at base, with small acute posterior and noticeable anterior angles; median cell broad, reaching anterior margin; lateral carinae curved; anterior cells roundish, diverging anteriorly, antero-lateral carinae short, curved, well developed. Mesothoracic spiracle hooded; hood long, narrow, erect. Scutellum transverse, narrowing distally, emarginate at apex (Fig. 24).

Elytra long, ca. 2.9 times longer than wide at humeri, narrowing distally, with strong, equally developed primary costae; interstices with small irregular roundish cells, interstices 1-4 with double rows of cells at proximal sixth; interstice 5 with double row of cells at proximal and distal fifths; bottom of cells glabrous; pubescence along costae, short and decumbent (Fig. 24).

Tibiae and femoris straight; tarsi slightly widened, tarsomeres 1-4 with plantar pad.

Aedeagus with bottle-shaped median lobe; inner sac with protruding elongate narrowing distally process (Figs 25-26).

Female. Unknown.

Length: $5.2 \mathrm{~mm}$. Width (humerally): $1.5 \mathrm{~mm}$.

ETYMOLOGY. The name of the new species is derived from the name of the locality where the type specimen was collected.

DIAGNOSIS. Procautires nabirensis sp.n. is quite unlike other Procautires, differing in the body shape, with relatively short and narrowed distally elytra, and the bottleshaped median lobe of the aedeagus with protruding elongate and narrowing distally inner sac process (Figs 24-26).

\section{Procautires sibelaensis Kazantsev, sp.n.} Figs 27-29.

MATERIAL: Holotype, $\sigma^{\top}$, N Moluccas, Bacan Is., Sibela Mt., $14 \mathrm{~km}$ SE Labuna, $400 \mathrm{~m}$, primary forest, 2-11.XI.1995, V. Siniaev \& E. Afonin leg. (ICM).

DESCRIPTION. Male. Dark brown to black; pronotal sides broadly, pro- and mesocoxae, trochanters and femoris, except distally, testaceous.

Vertex finely and densely punctate, with inconspicuous transverse impression behind antennal prominence. Eyes relatively small, interocular distance ca. 1.5 times shorter 
than eye diameter. Labrum transverse, slightly emarginate anteriorly. Palps slender, ultimate palpomeres elongate, pointed and glabrous distally. Antennal sockets separated by narrow lamina. Antennae flattened, relatively narrow, feebly dentate, attaining to elytral three fourths; antennomere $3 \mathrm{ca}$. 10 times longer than antennomere 2 and subequal in length to antennomere 4; antennomeres 3-11 with short sub-erect pubescence (Fig. 27).

Pronotum almost quadrate, ca. 1.1 times wider than long, with parallel sides, slightly produced anteriorly and bisinuate at base, with small acute posterior angles; median cell moderately broad, reaching 0.7 pronotal length; lateral carinae curved; anterior cells formed by straight, almost parallelsided antero-lateral carinae. Mesothoracic spiracle hooded; hood small, erect. Scutellum subquadrate, trapezoidal, incised at apex (Fig. 27).

Elytra narrow and long, ca. 3.9 times longer than wide at humeri, parallel-sided, slightly wider in proximal fourth, with strong, equally developed primary costae; interstices 1 and 5 with double rows of small regular roundish cells; interstice 2 with double row of cell, except at middle third; interstices 3 and 4 with double rows of cells only at proximal fourth; bottom of cells glabrous; pubescence mostly along costae, short and decumbent (Fig. 27).

Tibiae and femoris straight, narrow; tarsi widened, tarsomeres 1-4 with plantar pad.
Aedeagus with elongate, narrow median lobe widened in preapical part; membrane of phallobase with inner sclerotised structure (Figs 28-29).

Female. Unknown.

Length: $6.8 \mathrm{~mm}$. Width (humerally): $1.4 \mathrm{~mm}$.

ETYMOLOGY. The name of the new species is derived from the name of the mountains where the type specimen was collected.

DIAGNOSIS. Procautires sibelaensis sp.n. seems to be close to $P$. angustiformis sp.n., but may be differentiated by the longer antennae, black frons, broader testaceous lateral pronotal spots and concave pronotal sides, as well as by the less widened in the preapical part median lobe of the aedeagus (Figs 27-29).

\section{Procautires cygnus Kazantsev, sp.n.}

Figs 30-32.

MATERIAL: Holotype, $\sigma^{\top}$, Papua New Guinea, Madang prov., Baiteta, light, 28.V.1996, O. Missa leg. (IRCN).

DESCRIPTION. Male. Uniformly dark brown to black.

Vertex with two round impressions behind antennal prominence. Eyes relatively large, interocular distance subequal in length to eye diameter. Labrum small, transverse, truncate anteriorly. Palps slender; ultimate palpomeres small, rounded, pointed and glabrous at apex. Antennal sockets separated by minute lamina. Antennae flattened, relatively broad, fee-

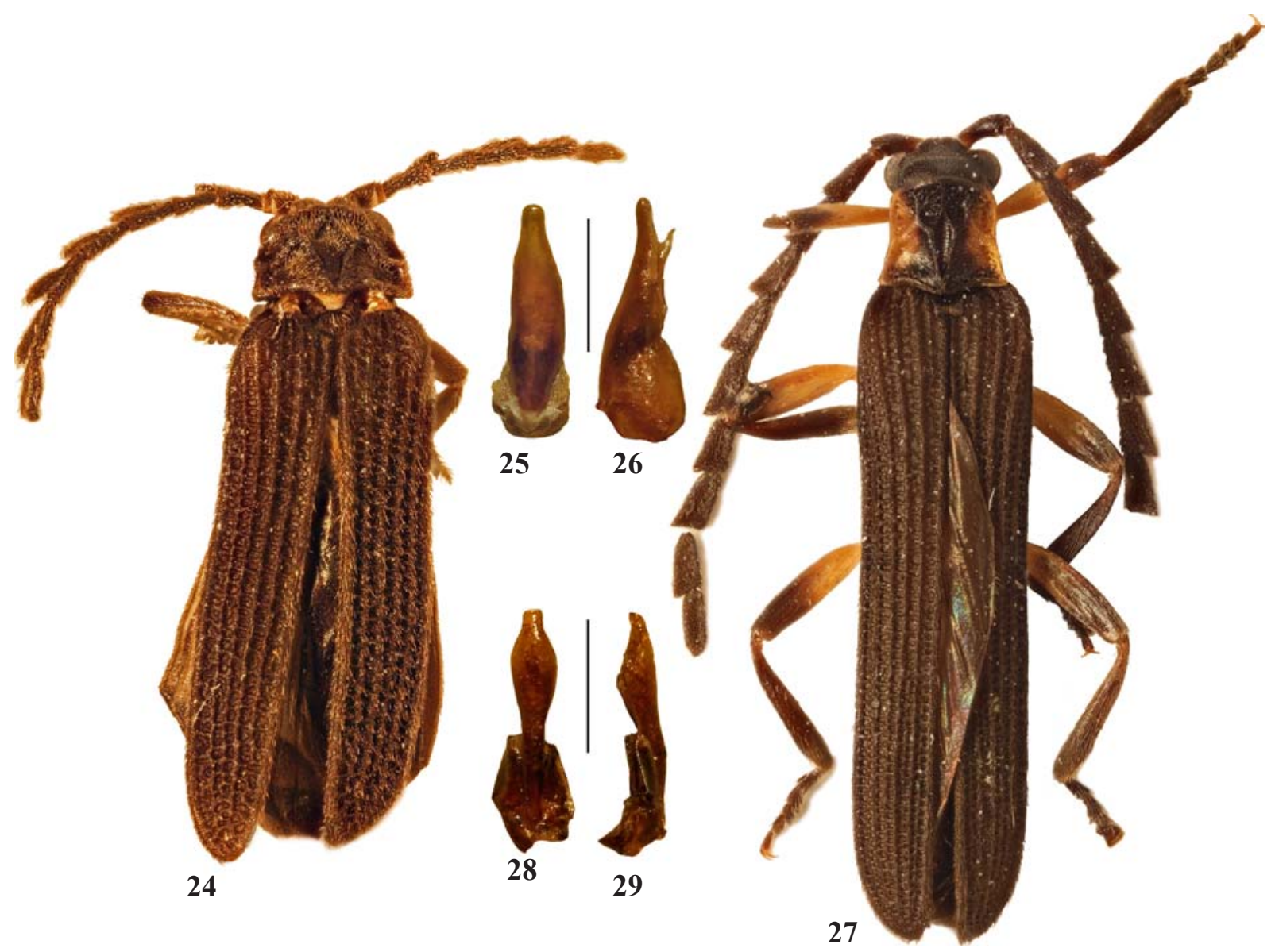

Figs 24-29. General view and aedeagi of Procautires, holotypes, males: 24-26 - P. nabirensis sp.n.; 27-29 - P. sibelaensis sp.n.; 24-27 - general view; 25-26, 28-29 - aedeagi; 24-25, 27-28 - dorsally; 26, 29 - laterally. Scale bars: $0.5 \mathrm{~mm}$.

Рис. 24-29. Общий вид и эдеагусы Procautires, голотипы, самцы: 24-26 - P. nabirensis sp.n.; 27-29 - P. sibelaensis sp.n.; 24 27 - общий вид; 25-26, 28-29 - эдеагусы; 24-25, 27-28 - сверху; 26, 29 - сбоку. Масштабные линейки: 0.5 мм. 
bly dentate; attaining to elytral two thirds; antennomere $3 \mathrm{ca}$. 7 times longer than antennomere 2 and 1.2 times shorter than antennomere 4; antennomeres 3-11 with short suberect pubescence and longer distal bristles (Fig. 30).

Pronotum transverse, ca. 1.4 times as wide as long, slightly narrowing anteriorly, bisinuate basally, with small acute posterior and conspicuous blunt anterior angles; median cell moderately broad, extending to 0.75 pronotal length; lateral carinae straight, diagonal; anterior cells not diverging anteriorly, formed by straight antero-lateral carinae. Mesothoracic spiracle short, not hooded. Scutellum transverse, rounded, deeply emarginate medially (Fig. 30).

Elytra long, ca. 3.6 times longer than wide at humeri, parallel-sided, with four primary costae; primary costa 3 noticeably weaker than other in distal two thirds; interstice 1 with double row of irregular cells; interstice 5 with double row of cells at proximal and distal fourths; interstices 2-4 with double rows of cells only at proximal fifth; bottom of cells glabrous; pubescence mostly along costae, short and decumbent (Fig. 30).

Tibiae and femoris straight, femoris broad; tarsi small, widened, tarsomeres 1-4 with plantar pad.

Aedeagus with narrow, but conspicuously widened api- cally median lobe; inner sac with three semi-oval sclerotised structures and a pair of lateral brushes; phallobase with flattened parameres-like sclerotised process, semi-enveloping median lobe (Figs 31-32).

Female. Unknown.

Length: $5.7 \mathrm{~mm}$. Width (humerally): $1.2 \mathrm{~mm}$.

ETYMOLOGY. The name of the new species is derived from the Latin for "swan", alluding to the shape of its aedeagus.

DIAGNOSIS. Procautires cygnus sp.n. seems to be related to P. multipilosus sp.n., but is readily separable by the larger eyes, more transverse pronotum, more parallel elytra and conspicuously widened apically median lobe of the aedeagus with differently arranged inner sac structures (Figs 30-32).

\section{Procautires wauvagus Kazantsev, sp.n.} Figs 33-35.

MATERIAL: Holotype, ơ, Papua New Guinea, Morobe Pr., Wau, Big Wau Creek, 1200 m, 12.IX.1995, J. Scott leg. (ICM).

DESCRIPTION. Male. Black; elytral proximal third and very bases of trochanters and femoris testaceous.

Head anteriorly without rostrum. Vertex shining, finely

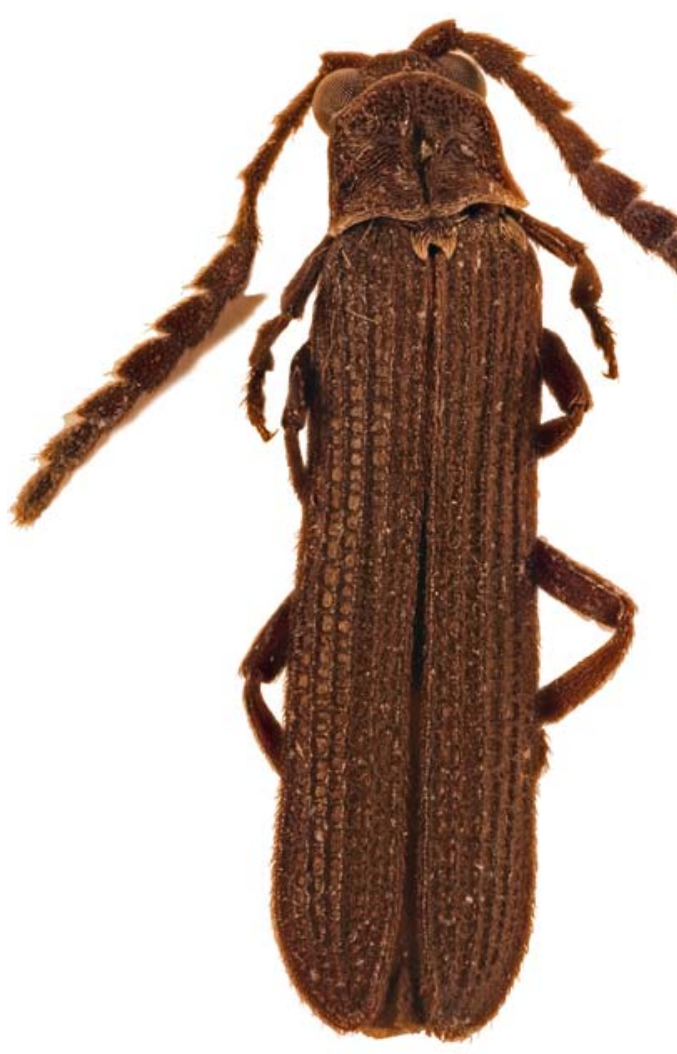

30

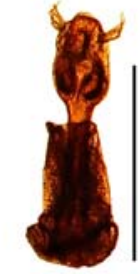

31

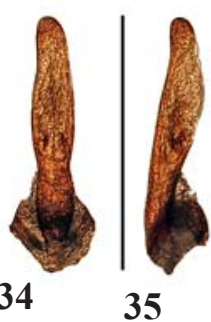

34

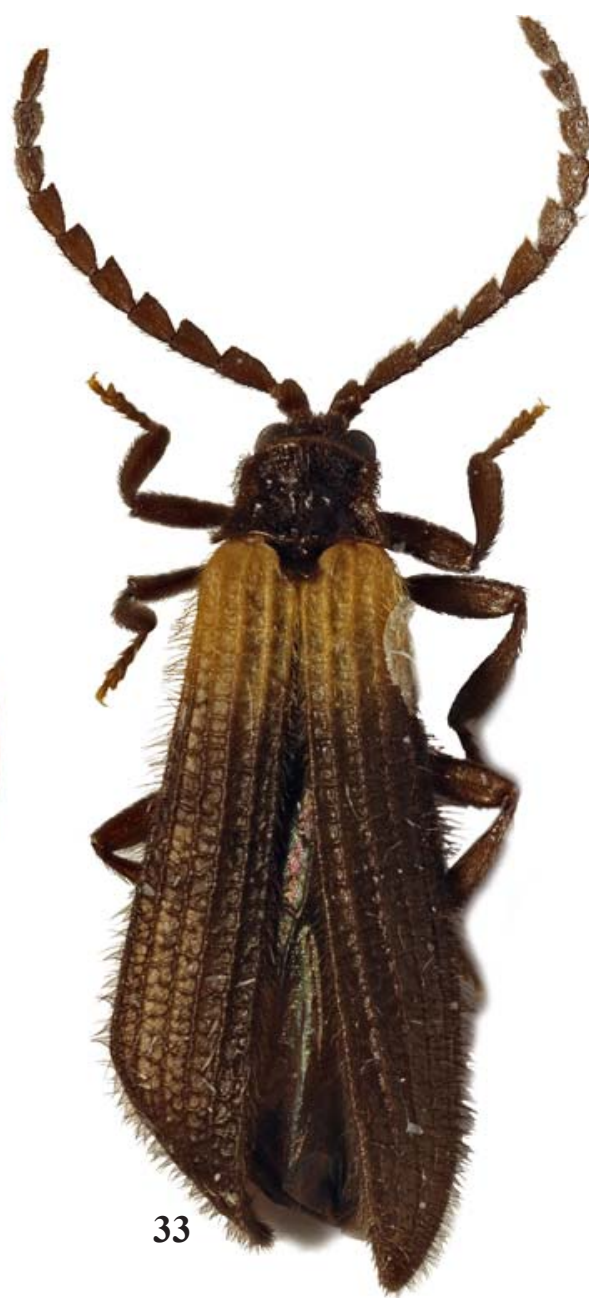

Figs 30-35. General view and aedeagi of Procautires, holotypes, males: 30-32 - P. cygnus sp.n.; 33-35 - P. wauvagus sp.n.; 30, 33 - general view; 31-32, 34-35 - aedeagi; 30-31, 33-34 - dorsally; 32 , 35 - laterally. Scale bars: $0.5 \mathrm{~mm}$.

Рис. 30-35. Общий вид и эдеагусы Procautires, голотипы, самцы: 30-32 - P. cygnus sp.n.; 33-35 - P. wauvagus sp.n.; 30, 33 - общий вид; 31-32, 34-35 - эдеагусы; 30-31, 33-34 - сверху; 32, 35 - сбоку. Масштабные линейки: 0.5 мм. 
punctate, with transverse impression behind antennal prominence. Eyes moderately large, interocular distance ca. 1.3 times shorter than eye diameter. Labrum small, slightly wider than long, semi-circularly emarginate anteriorly. Palps slender, ultimate palpomeres elongate, narrowed and glabrous distally. Antennal sockets separated by minute lamina. Antennae flattened, relatively broad, dentate, attaining to elytral two thirds; antennomere 3 ca. 5 times longer than antennomere 2 and ca. 1.1 times longer than antennomere 4; antennomeres 3-11 with short erect pubescence (Fig. 33).

Pronotum ca. 1.65 times wider than long, parallel-sided, convex anteriorly and bisinuate at base, with strongly produced acute posterior angles; median cell narrow, extending to 0.7 pronotal length; lateral and antero-lateral carinae almost obsolete, with lateral carinae noticeable only near sides; antero-lateral carinae noticeable only near median cell; pronotal pubescence relatively long, dense and decumbent. Mesothoracic spiracle hooded; hood moderately long, erect. Scutellum subquadrate, parallel-sided, triangularly emarginate at apex (Fig. 33).

Elytra long, ca. 3.6 times longer than wide at humeri, widening posteriorly, with strong, equally developed primary costae; interstices $1-5$ with double rows of irregular cells only in distal half; bottom of cells finely alveolate; pubescence along costae, relatively long and erect (Fig. 33).

Tibiae and femoris straight, narrow; tarsi small, narrow.

Aedeagus with lanceolate median lobe, inner sac with a pair of basal sclerotised spines (Figs 34-35).

Female. Unknown.
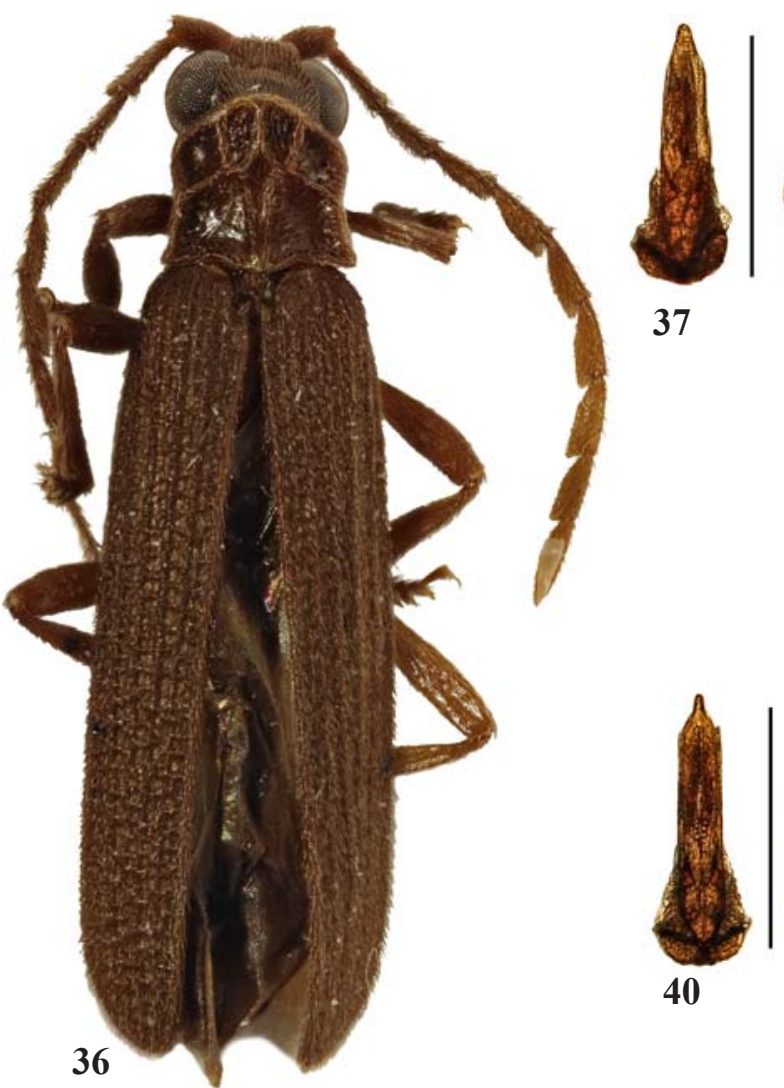

37

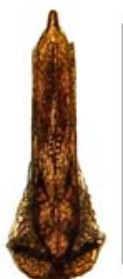

40
Length: $6.5 \mathrm{~mm}$. Width (humerally): $1.4 \mathrm{~mm}$.

ETYMOLOGY. The name of the new species is derived from the name of the locality where the type specimen was collected and the Latin for "wandering".

DIAGNOSIS. Procautires wauvagus sp.n. may be distinguished from all Procautires species by the elytral coloration and vestiture: they are black with anterior third testaceous and covered with long erect hairs, as well by lanceolate median lobe of the aedeagus (Figs 33-35).

\section{Procautires aflabellatus Kazantsev, sp.n.} Figs 36-38.

MATERIAL: Holotype, $\sigma^{7}$, Papua New Guinea, Madang prov., Baiteta, light, 23.IV.1996, O. Missa leg. (IRCN); paratypes, 10 $0^{7} O^{7}$, same label, dates: 23.IV.1996; 16.IV.1994; 16.IV.1995; 4.V.1996 (2 specimens); 15.V.1996; 20.V.1996; 4.VI.1996; 11.VII.1996; 24.VII.1996; 8 क⿱ , same label, dates: 16.IV.1994; 9.IV.1996; 11.IV.1996 (2 specimens); 17.IV.1996; 4.V.1996 (2 specimens); 24.VII.1996 (ICM and IRCN).

DESCRIPTION. Male. Uniformly dark brown to black.

Vertex with conspicuous transverse impression behind antennal prominence. Eyes large, interocular distance 1.4 times shorter than eye diameter. Labrum small, transverse, truncate anteriorly. Palps slender; ultimate palpomeres small, elongate, narrowed and glabrous at apex. Antennal sockets separated by minute lamina. Antennae flattened, relatively broad, dentate; attaining to elytral two thirds; antennomere 3 almost 10 times longer than antennomere 2 and ca. 1.1 times longer than antennomere 4; antennomeres 3-11 with short suberect pubescence (Fig. 36).

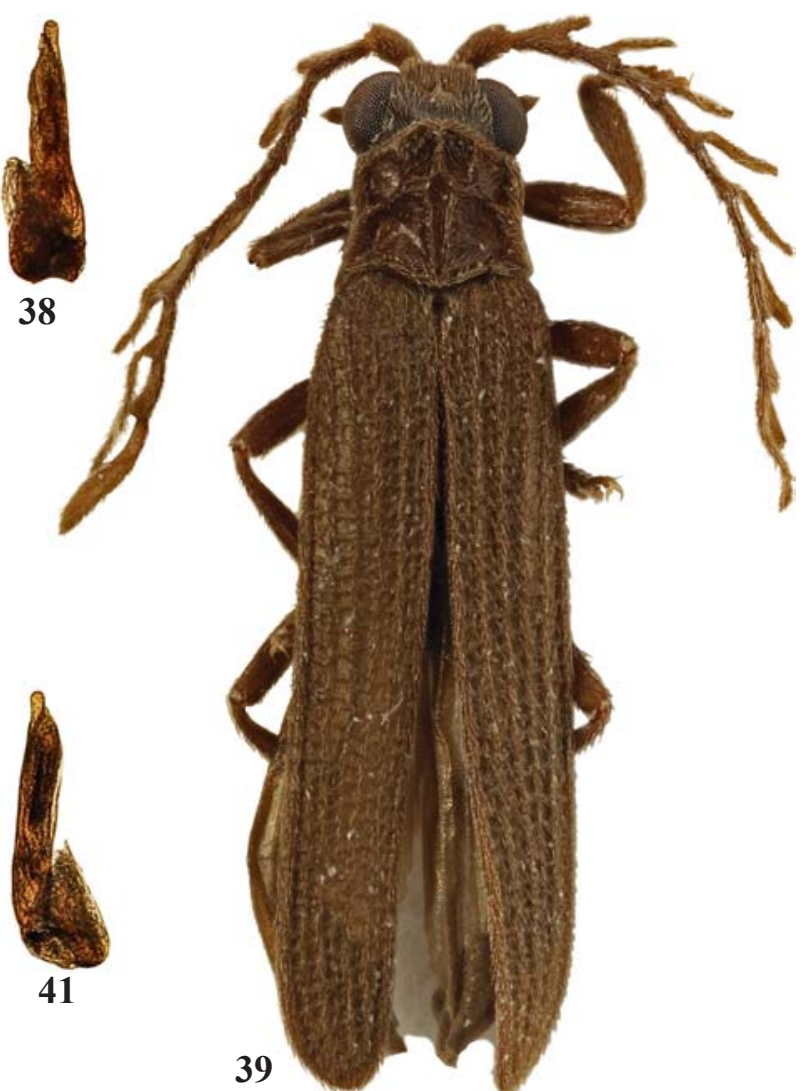

Figs 36-41. General view and aedeagi of Procautires, holotypes, males: 36-38 - P. aflabellatus sp.n.; 39-41 - P. nigropumilio sp.n.; 36, 39 - general view; 37-38, 40-41 - aedeagi; 36-37, 39-40 - dorsally; 38, 41 - laterally. Scale bars: $0.5 \mathrm{~mm}$.

Рис. 36-41. Общий вид и эдеагусы Procautires, голотипы, самцы: 36-38 - P. aflabellatus sp.n.; 39-41 - P. nigropumilio sp.n.; 36, 39 - общий вид; 37-38, 40-41 - эдеагусы; 36-37, 39-40 - сверху; 38, 41 - сбоку. Масштабные линейки: 0.5 мм. 
Pronotum nearly quadrate, ca. 1.1 times as wide as long, slightly concave at sides triangularly produced anteriorly and bisinuate basally, with small acute posterior and conspicuous blunt anterior angles; median cell moderately broad, extending to 0.8 pronotal length; lateral carinae straight, diagonal; anterior cells slightly diverging anteriorly, formed by straight antero-lateral carinae. Mesothoracic spiracle short, not hooded. Scutellum transverse, almost parallel-sided, deeply emarginate medially (Fig. 36).

Elytra long, ca. 3.5 times longer than wide at humeri, parallel-sided, with four equally developed primary costae; interstices 1, 4 and 5 with double rows of irregular subquadrate cells, interstice 4 disappearing at elytral four fifths; interstices $2-3$ with double rows of cells at proximal and distal fourths; bottom of cells hairless; pubescence dense, short and decumbent (Fig. 36).

Tibiae and femoris straight, moderately broad; tarsi small, widened, tarsomeres 2-4 with plantar pad (tarsomere 1 with minute apical plantar pad).

Aedeagus with straight, relatively narrow, evenly narrowed distally median lobe; inner sac with paired basal structure and a pair of lanceolate structures distally (Figs 3738).

Female. Similar to male, but eyes smaller.

Length: 4.7-4.9 mm. Width (humerally): $1.0-1.1 \mathrm{~mm}$.

ETYMOLOGY. The name of the new species is derived from the Latin for "flabellate", and the negative prefix "a-", alluding to the structure of its antennae.

DIAGNOSIS. Procautires aflabellatus sp.n. is easily separated from most other Procautires species by the dark brown to black upperside and subquadrate cells in the elytral interstices (Fig. 36); it can be distinguished from the similarly coloured and having similar elytral reticulation $P$. nigropumilio sp.n. by the non-flabellate male antennae and evenly narrowed distally median lobe of the aedeagus (Figs 36-38).

REMARKS. In some of the paratypes elytral interstices 2-3 have traces of complete double rows of cells in all their length.

\section{Procautires nigropumilio Kazantsev, sp.n.} Figs 39-41.

MATERIAL: Holotype, Ơ', Papua New Guinea, Madang prov., Baiteta, light, 8.IV.1996, O. Missa leg. (IRCN); paratypes, $2 \sigma^{7} \sigma^{\prime}$, same label, dates: 4.V.1996; 29.V.1996 (ICM and IRCN).

DESCRIPTION. Male. Uniformly dark brown to black.

Vertex with two small deep round impressions behind antennal prominence. Eyes relatively large, interocular distance ca. 1.1 times greater than eye diameter. Labrum small, transverse, rounded anteriorly. Palps slender; ultimate palpomeres elongate, pointed and glabrous at apex. Antennal sockets separated by narrow lamina. Antennae almost attaining to elytral two thirds, from antennomere 3 flabellate; antennomere $3 \mathrm{ca} .7$ times longer than antennomere 2 and 1.3 times longer than antennomere 4; flabella of antennomere 3 ca. 2.2 times shorter than stem, flabella of antennomere $4 \mathrm{ca}$. 1.3 times and flabella of antennomere $5 \mathrm{ca} .1 .7$ times longer than relevant stems; antennomeres 3-11 with short sub-erect pubescence (Fig. 39).

Pronotum almost quadrate, ca. 1.1 times as wide as long, slightly concave before posterior angles, bisinuate basally and strongly produced anteriorly, with acute posterior and conspicuous blunt anterior angles; median cell relatively narrow, extending to 0.7 pronotal length; lateral carinae slightly convex; anterior cells slightly diverging anteriorly, formed by straight antero-lateral carinae. Mesothoracic spir- acle small, short, not hooded. Scutellum subquadrate, parallel-sided, deeply emarginate at apex (Fig. 39).

Elytra long, ca. 3.6 times longer than wide at humeri, parallel-sided, with four equally developed primary costae; interstices 1 and 5 with double rows of irregular subquadrate cells at proximal and distal fourths; interstice 2 with double row of cells at proximal fourth and distal fifth; interstices $3-$ 4 with double rows of cells only at proximal fifths; bottom of cells hairless, glabrous; pubescence short and decumbent (Fig. 39).

Tibiae and femoris straight, narrow; tarsomeres 2-4 with plantar pad (tarsomere 1 with minute apical planter pad).

Aedeagus with straight, relatively narrow, abruptly constricted apically median lobe; inner sac with paired basal structure and a pair of lanceolate structures distally (Figs 4041).

Female. Unknown

Length: 4.4-4.5 mm. Width (humerally): $1.0-1.1 \mathrm{~mm}$.

ETYMOLOGY. The name of the new species is derived from the Latin for "black" and "small", alluding to its size and coloration.

DIAGNOSIS. Procautires nigropumilio sp.n. can be separated from the habitually similar $P$. aflabellatus sp.n. by the flabellate antennae, as well as by the abruptly constricted apically median lobe of the aedeagus (Figs 39-41).

\section{Procautires maklaii Kazantsev, sp.n.}

Fig. 42.

MATERIAL: Holotype, $\uparrow$, Indonesia, Irian Jaya, $50 \mathrm{~km} \mathrm{~S} \mathrm{Nabi-}$ re, Pusppenssat, 750 m, 31.XII.1997, A. Weigel leg. (NME).

DESCRIPTION. Female. Dark brown to black; antennomere 2 and very bases of other antennomeres, trochanters and very bases of femoris light brown.

Vertex with noticeable triangular impression behind antennal prominence. Eyes small, interocular distance ca. 2 times greater than eye diameter. Labrum relatively large, transverse, rounded and emarginate anteriorly. Maxillary palps relatively robust; ultimate palpomere elongate, narrowed apically. Labial palps slender; ultimate palpomere elongate, pointed and glabrous at apex. Antennal sockets separated by narrow lamina. Antennae attaining to elytral three fourths, broad, from antennomere 4 moderately flabellate; antennomere $3 \mathrm{ca} .10$ times longer than antennomere 2 and 1.4 times longer than antennomere 4 ; antennomeres 3-11 with short decumbent pubescence (Fig. 42).

Pronotum transverse, ca. 1.3 times wider than long, narrowing anteriorly, slightly bisinuate basally, slightly concave before posterior angeles, with moderately protruding acute posterior and noticeable blunt anterior angles; median cell relatively broad, extending to 0.8 pronotal length; lateral carinae concave; anterior cells relatively small, somewhat rounded, formed by straight antero-lateral carinae. Mesothoracic spiracle prominent, hooded; hood elongate, flattened and bent posteriad. Scutellum transverse, parallel-sided, slightly rounded and emarginate at apex (Fig. 42).

Elytra long, ca. 3.4 times longer than wide at humeri, parallel-sided, with strong, equally developed primary costae; interstices 1 and 5 with double rows of regular transverse cells; interstices 2-4 with double rows of cells only at proximal sixth; bottom of cells hairless; pubescence short and decumbent (Fig. 42).

Tibiae and femoris straight, femoris relatively broad; tarsi widened, tarsomeres 1-4 with plantar pad.

Male. Unknown.

Length: $11.5 \mathrm{~mm}$. Width (humerally): $2.8 \mathrm{~mm}$. 
ETYMOLOGY. The new species is named after the famous XIX century explorer of New Guinea N.N. Miklukho-Maklai.

DIAGNOSIS. Procautires maklaii sp.n. may be separated from the similar in terms of antennal, pronotal and elytral structure $P$. angustisuturalis sp.n. and $P$. cladophoroides sp.n. by the coloration and the definitely broader antennae (Fig. 42).

\section{Procautires miklukhai Kazantsev, sp.n.} Fig. 43.

MATERIAL: Holotype, + , E Indonesia, West Papua, S Bird's Neck, 7-9 km NW Kaimana, 0335'02'S, $133^{\circ} 42^{\prime} 58^{\prime \prime}$ E, 25-200 $\mathrm{m}$, primeval lowland rainforest on limestone, 5.IX.2010, D. Telnov leg. (NME)

DESCRIPTION. Female. Dark brown to black; scapus basally, antennomere 2, pronotal sides, elytral shoulders, trochanters, proximal halves of femoris and bases if tibiae orange testaceous.

Vertex with transverse impression behind antennal prominence. Eyes small, interocular distance ca. 1.7 times greater than eye diameter. Labrum relatively large, transverse, rounded, slightly emarginate medially. Palps slender; ultimate palpomeres elongate, narrowed and glabrous at apex. Antennal sockets separated by narrow lamina. Antennae attaining to elytral three fifths, from antennomere 3 dentate; antennomere $3 \mathrm{ca} .10$ times longer than antennomere 2 and 1.1 times longer than antennomere 4; antennomeres 3-11 with short decumbent pubescence (Fig. 43).

Pronotum transverse, ca. 1.6 times wider than long, narrowing and rounded anteriorly, bisinuate basally, with protruding acute posterior angles; median cell relatively broad, extending to 0.6 pronotal length; lateral carinae concave; anterior cells slightly diverging anteriorly, formed by straight antero-lateral carinae. Mesothoracic spiracle hooded; hood flattened, bent posteriad. Scutellum transverse, strongly narrowing distally, semi-circularly emarginate at apex (Fig. 43).

Elytra long, ca. 3.3 times longer than wide at humeri, parallel-sided, with strong, equally developed primary costae; interstices 1 and 5 with double rows of regular roundish cells; interstices 2-4 with double rows of cells at proximal fifths and distal sixths; bottom of cells hairless; pubescence short and decumbent (Fig. 43).

Tibiae and femoris straight, relatively narrow; tarsi widened, tarsomeres 1-4 with plantar pad.

Male. Unknown.

Length: $7.2 \mathrm{~mm}$. Width (humerally): $1.8 \mathrm{~mm}$.

ETYMOLOGY. The new species is named after the famous XIX century explorer of New Guinea N.N. Miklukho-Maklai.
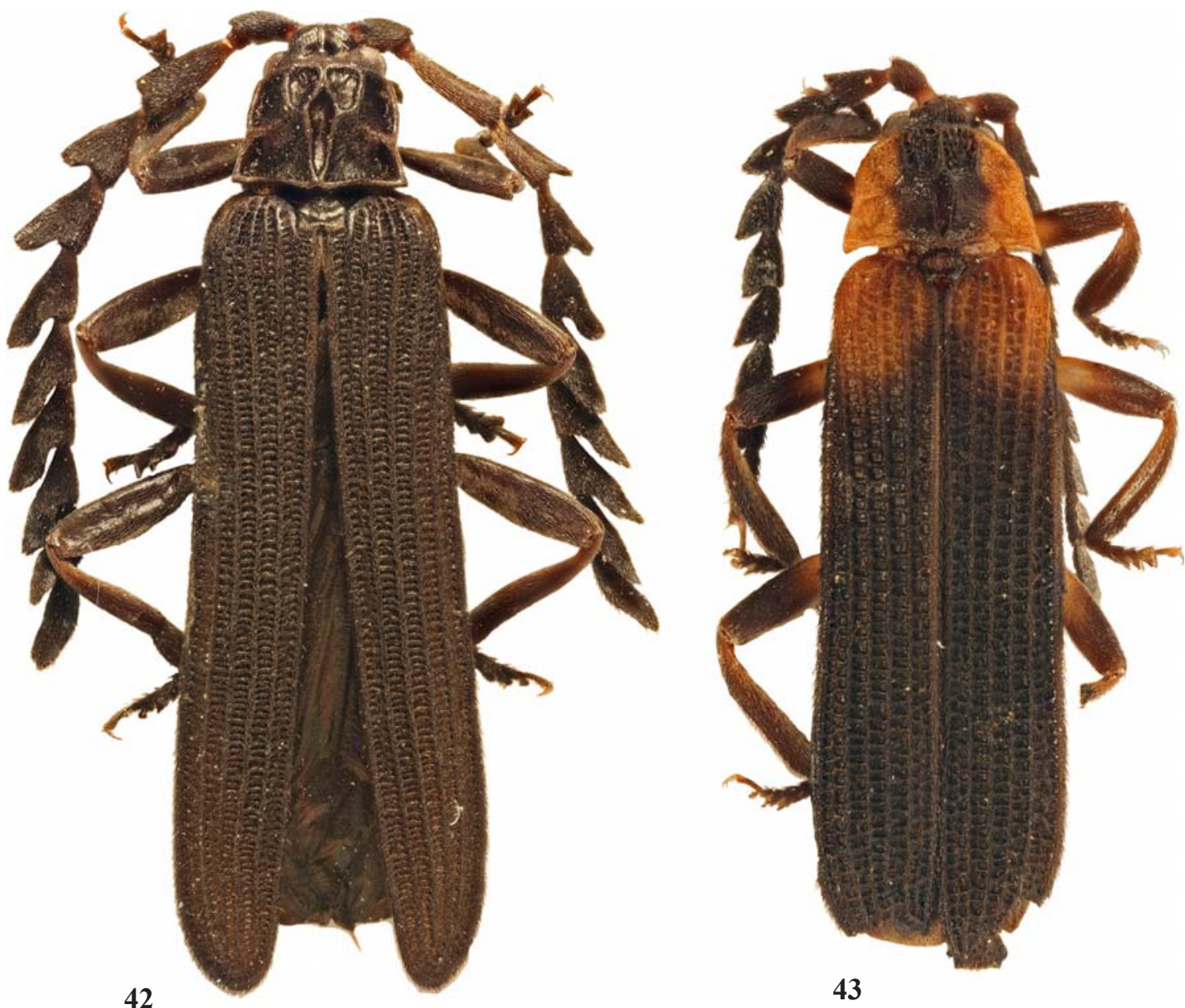

Figs 42-43. General view of Procautires, holotypes, females: $42-$ P. maklaii sp.n.; $42-$ P. miklukhaii sp.n.

Рис. 42-43. Общий вид Procautires, голотипы, самки: $42-$ P. maklaii sp.n.; $43-$ P. miklukhaii sp.n. 
DIAGNOSIS. Procautires miklukhai sp.n. can be easily separated from congeners by the coloration and antennal and pronotal structure (Fig. 43).

\section{Discussion}

The genus Procautires is characterized by the flabellate in male and serrate in female antennae, absent secondary elytral costae in the middle of elytra at least in some of the interstices, and slender, widened apically median lobe of the aedeagus with sclerotised in basal part inner sac structure and pigmented phallobasal membrane [Kleine, 1925; Bocák, 2002]. Of these only the elytral structure is the unique autapomorphy of Procautires, the rest shared by some of the other metriorrhynchines. The present study has revealed, however, that these characters are very variable in taxa with the Procautires-type elytral structure. The antennae may be only feebly dentate in the male (e.g., Figs 1, 30), the median lobe of aedeagus may vary from bottle-shaped to very narrow and not widened distally (e.g., Figs $21-$ $22,25-26,34-35)$, the inner sac sclerotised parts may include both elongate complex internal structures and surface patches with brushes of setae (e.g., Figs 8-9, 16-17, 21-22, 31-32) and the phallobasal membrane may transform into elongate and well sclerotised parameres-like structures (e.g., Figs 21-22, 31-32)

In addition, the following frequently used or potentially usable in supraspecific taxonomy characters have also been found to vary considerably in the species studied: the structure of ultimate palpomeres, antennal and elytral vestiture, shape and length of the median pronotal cell, structure of the mesothoracic spiracles, structure of the external and internal female genitalia.

In this respect it seems quite probable that Procautires actually represents a polyphyletic taxon, with inclusion of taxa from current (also possibly polyphyletic)
Cladophorus Guerin-Meneville, 1830, Porrostoma Laporte, 1838, Cautires Waterhouse, 1879, Xylobanus Waterhouse, 1879 and related genera. The actual phylogeny of this lineage of net-winged beetles is in apparent need of re-examination on the basis of a comprehensive phylogenetic analysis.

ACKNOWLEDGEMENTS. It is my pleasant duty to express gratitude to Dr. P. Grootaert (Institut Royal de Sciences naturelles de Belgique, Bruxelles), Dr. M. Hartmann (Naturkundemuseum Erfurt) and Dr. D. Telnov (Entomological Society of Latvia, Riga), through whose courtesy I was able to study the Lycidae collections under their care. My sincere thanks are also due to Dr. R. Holyński (Milanowek, Poland), Dr. A. Kopetz (Kerspleben) and Mr. V. Siniaev and Dr. V. Tuzov (Moscow) for providing interesting material collected during their entomological expeditions to New Guinea and adjacent islands.

\section{References}

Bocák L. 2002. Generic revision and phylogenetic analysis of the Metriorrhynchinae (Coleoptera: Lycidae) // European Journal of Entomology. Vol.99. P.315-351.

Kleine R. 1925. Fauna Buruana. Coleoptera, Fam. Lycidae (2. Beitrag zur Kenntnis der Lycidae)// Treubia. B.7. H.1. S.31-37.

Kleine R. 1926. Coleoptera. Lycidae// Nova Guinea. Résultats des Expéditions scientifiques à la Nouvelle Guinée. Vol.15. Leiden: E.J. Brill. P.91-195.

Kleine R. 1933. Pars 123: Lycidae // Coleopterorum Catalogus auspiciis et auxilio W. Junk editus a Schenkling. Berlin: W. Junk. P.145.

Kleine R. 1935. Bericht über die von Miss Cheesman in British NeuGuinea gesammelten. Brenthiden und Lyciden. Nova Guinea // Résultats des Expéditions scientifiques à la Nouvelle Guinée. Vol.17. Leiden: E.J. Brill. P.309-321.

Riedel A. 2008. Three new species of Euops Schoenherrr from the forest canopy in Papua New Guinea (Coleoptera, Curuculionoidea, Attelabidae) // Mitteilungen der Münchner Entomologischen Gesellschaft. B.98. S.127-142. 